\title{
Interventions Implemented to Reduce the Risk of Transmission of Bacteria by Transfusion in the English National Blood Service
}

\author{
Carl P. McDonald \\ NHS Blood and Transplant, London, UK
}

\section{Keywords}

Bacterial contamination - Blood donation - Blood safety . Haemovigilance - Platelet concentrates, Transfusion reaction . Transfusion risks - Transfusion-associated infections . Bacteria - Diversion · Disinfection

\section{Summary}

Background: Bacterial contamination remains a significant problem in transfusion medicine. A National Health Service Blood and Transplant (NHSBT) study and surveillance data indicated skin commensals derived from the skin of the donor are the major contaminants of blood components. NHSBT therefore explored two interventions: improved donor arm disinfection and diversion. Methods: Improved donor arm disinfection: Commercial and inhouse methods of disinfection were evaluated. Swabs at the venepuncture site were taken before and after disinfection and the reduction in bioburden determined. Diversion: Special collection bags were manufactured to allow the initial volume of blood to flow into a pouch, representing the diversion pouch and then the next flow of blood into another pouch representing the collection bag. Pouches were screened for the presence of bacteria. The reduction in bacterial contamination was then determined. Results: A two-step commercial procedure (Donor Prep Kit; DPK) consisting of $70 \%$ isopropyl alcohol followed by tincture of iodine was shown to be a best practice procedure (2-min procedure). A $99.79 \%$ reduction was obtained, and this method was 10 times more effective than current practice at that time. The DPK was shown in a field trial to increase donor waiting time. A second study was initiated to find a more rapid procedure. ChloraPrep ${ }^{\circledR}$, consisting of $2 \%$ chlorhexidine gluconate and $70 \%$ isopropyl alcohol, was shown to have equivalent disinfection efficiency as the DPK, but only took $1 \mathrm{~min}$ to perform. In 2006, ChloraPrep was introduced as the national method of donor arm disinfection. Diversion was shown to give a $47 \%$ reduction in contamination and was introduced nationally in 2002. Conclusion: Improved donor arm disinfection and diversion are effective, low-cost interventions, but do not eliminate all bacterial transmissions. In 2011, bacterial screening of platelet components was introduced by NHSBT to further increase the safety of the blood supply.

\section{Schlüsselwörter}

Bakterielle Kontamination - Blutspende - Blutsicherheit . Hämovigilanz · Thrombozytenkonzentrate - Transfusionsreaktion . Transfusionsrisiken · Transfusionsassoziierte Infektionen . Bakterien · Diversion · Desinfektion

\section{Zusammenfassung}

Hintergrund: Die bakterielle Kontamination bleibt ein bedeutendes Problem in der Transfusionsmedizin. Eine Health Service Blood and Transplant(NHSBT)-Studie und Überwachungsdaten weisen darauf hin, dass Hautkommensalen von der Haut des Spenders die Hauptverunreinigungen von Blutkomponenten darstellen. Die NHSBT untersuchte daher zwei Interventionen - verbesserte Spenderarmdesinfektion und Diversion. Methoden: Verbesserte Spenderarmdesinfektion: Sowohl kommerzielle und als In-Haus-Methoden wurden evaluiert. An der Einstichstelle wurden vor und nach Desinfektion Abstriche gemacht und dann die Reduzierung der Biobelastung bestimmt. Diversion: Spezielle Sammelbeutel wurden hergestellt, bei denen die ersten Milliliter gesammelten Bluts in einen separaten Beutel, den Diversionsbeutel, fließen und die Rest der Blutspende in einem weiteren Beutel, dem Spendebeutel, aufgefangen wird. Die Beutel wurden dann auf das Vorahndensein von Bakterien untersucht und die Reduktion der bakteriellen Kontamination bestimmt. Ergebnisse: Ein kommerzielles Zwei-Schritt-Verfahren (Donor Prep Kit; DPK), das aus 70\% Isopropylalkohol gefolgt von einer Jodtinktur besteht, erwies sich in der Praxis als bestes Verfahren (2-min-Verfahren). So ließ sich eine $99,79 \%$ ige Reduktion erzielen, diese Methode war damit zehnmal effektiver als das zu diesem praktizierte Standardverfahren. In einer Feldstudie zeigte sich, dass DPK die Spenderwartezeit verlängert. Eine zweite Studie wurde gestartet, um ein schnelleres Verfahren zu finden. Chlora Prep $^{\circledR}$, das aus $2 \%$ Chlorhexidin-Glukonat und $70 \%$ Isopropylalkohol besteht, zeigte eine gleichwertige Desinfektionseffizienz wie DPK, erlaubte aber, das Desinfektionsverfahren auf $1 \mathrm{~min}$ zu verkürzen. 2006 wurde ChloraPrep als nationale Standardmethode zur Spenderarmdesinfektion eingeführt. Durch die Diversion wurde eine $47 \%$ ige Reduktion der Kontamination erreicht, dieses Verfahren wurde 2002 national verpflichtend. Schlussfolgerung: Verbesserte Spenderarmdesinfektion und Diversion sind wirksame und billige Verfahren, sie können aber nicht alle bakteriellen Kontaminationen vermeiden. 2011 wurde von der NHSBT daher das bakterielle Screening von Thrombozytenkonzentraten eingeführt, um die Sicherheit der Blutversorgung weiter zu steigern.

\begin{tabular}{|c|c|}
\hline KARGER & (C) 2011 S. Karger GmbH, Freiburg \\
\hline $\begin{array}{l}\text { Fax +497614520714 } \\
\text { Information@Karger.de } \\
\text { www.karger.com }\end{array}$ & $\begin{array}{l}\text { Accessible online at: } \\
\text { www.karger.com/tmh }\end{array}$ \\
\hline
\end{tabular}

Dr. Carl P. McDonald

NHS Blood and Transplant

Colindale Avenue

Colindale London NW9 5BG, UK

Tel. +44 208957 27-32, Fax -24

carl.mcdonald@nhsbt.nhs.uk 


\section{Introduction}

Since the 1970s, the risk of viral transmission by transfusion has been markedly reduced [1]. Transmission of bacteria by transfusion is not a new problem, having been reported nearly 70 years ago $[2,3]$. In the mid 1990s, the attention of the blood community was drawn to bacterial transmissions due to case reports in the literature and the establishment of haemovigilance systems. In 1995 the U.K. Serious Hazards of Transfusion (SHOT) voluntary surveillance system was established, reporting that between 1995 and 2001 bacterial transmissions accounted for $64 \%(21 / 33)$ of microbial transmissions [4]. In this period in the UK, $85 \%(6 / 7)$ of microbial fatalities reported to SHOT were due to transmission of bacteria by transfusion. Platelet concentrates accounted for $81 \%$ (17/21) of these transmissions.

From 1994 to 1998, the French haemovigilance surveillance system (a mandatory requirement under French law), attributed 18 deaths (four occurring in 1997) to blood components contaminated with bacteria [5, 6]. Between 1994 and 1999, bacterial transmissions comprised $22 \%$ of total transfusionassociated fatalities [7]. Transmission of bacteria by transfusion was reported to the haemovigilance surveillance system as the most frequently identified cause of death [5].

In the USA, from 1985 to 1999 bacterial contamination was second only to haemolytic reactions as the most frequent reported cause of mortality, accounting for over $10 \%(77 / 694)$ of transfusion fatalities [8]. From 2001 to 2003, the transmission of bacteria by transfusion accounted for 37 deaths, amounting to $14.1 \%$ of all transfusion fatalities [9].

A National Health Service Blood and Transplant (NHSBT) retrospective monitoring study was established in 1995 to determine the bacterial contamination rate in blood components using an automated microbial detection system $[10,11]$. The study was also used to determine the effectiveness of any interventions implemented to reduce bacterial contamination.

Data from this study and SHOT surveillance data indicated that the vast majority of organisms that contaminate blood components are skin commensals derived from the skin of the donor at venepuncture. NHSBT therefore explored two interventions:

- improved donor arm disinfection,

- diversion.

\section{Material and Methods}

\section{Improved Donor Arm Disinfection}

A study was undertaken to determine the effectiveness of in-house and commercial disinfection protocols [12]. Swabbing of the venepuncture site was performed before and after disinfection. Swabs were inoculated onto agar plates, and the reduction in bioburden pre and post disinfection was determined. A second study was undertaken to derive a disinfection procedure that would only take $1 \mathrm{~min}$ to perform [13].

\section{Diversion}

In 1995, Olthuis et al. [14] proposed that diversion of the initial volume of blood donation from the collection bag had the potential to dramatically reduce bacterial contamination. The rationale behind this is that (as previously mentioned) the major source of bacterial contamination of blood components occurs at the collection stage, due to inadequate donor arm disinfection and/or a small core of skin entering the collection bag from coring by the phlebotomy needle. Re-direction of the initial flow of blood from the collection bag into a pouch or side arm would thus reduce the risk of bacterial contamination of the donation contents.

Special collection bags were manufactured for a study to determine the effectiveness of diversion [15]. These bags consisted of two sampling pouches attached to the standard collection bag configuration. At donation, blood was made to flow initially into pouch $\mathrm{P} 1$, which represented a diversion pouch. Pouch P1 was then closed causing the blood to flow into pouch $\mathrm{P} 2$, which acted as a representative sample of the collection bag post diversion. P2 was then closed, and blood was diverted into the collection bag as in a routine donation. The pouches were sampled and inoculated into culture bottles and incubated on an automated microbial detection system for 7 days. Any bacteria that grew were sub-cultured and identified.

\section{Results}

\section{Improved Donor Arm Disinfection}

The Donor Prep Kit (DPK) (Enturia (formerly Medi-Flex), Leadwood, KS, USA) was shown to be a best-practice technique, consisting of an initial application of isopropyl alcohol and tincture of iodine. The procedure took $2 \mathrm{~min}$, with an application time of $30 \mathrm{~s}$ and drying time of $30 \mathrm{~s}$ for each disinfectant. A percentage reduction of $99.79 \%\left(\log _{10}\right.$ reduction $\left.2.67 \%\right)$ was obtained compared with $78.2 \%\left(\log _{10}\right.$ reduction $1.31 \%$ ) for the then current method, $0.5 \%$ chlorhexadine isopropyl alcohol wipe (Guardpack, Chelmsford, Essex, UK) [12].

The DPK was implemented for apheresis platelet donations in July 2001, and the reduction in the bacterial contamination rate of time-expired platelet donations was shown to be $57 \%$ [16]. Previously an experimental study predicted a $57 \%$ reduction in contamination [15]. A $67 \%$ reduction in clinically apparent cases of bacterial transmission following transfusion of NHSBT blood donations reported to SHOT was observed [17]. In the period 1997 to 2000 prior to implementation, 6 clinical cases (including 2 deaths) were reported. After the introduction of the DPK at apheresis clinics in the 4-year period from July 2001 to 2005, only 2 clinically apparent reactions from transfusion of platelet concentrates manufactured by NHSBT have been reported.

An extensive field evaluation of the use of the DPK procedure has been undertaken at mobile blood donor sessions. It was however, deemed inappropriate for routine use by NHSBT because it would increase donor waiting times. This was due to the additional $1 \mathrm{~min}$ that was required with the DPK compared with the routine method in use at that time. The NHSBT National Bacteriology Laboratory (NBL) was therefore tasked with identifying a disinfection procedure that was of comparable disinfection efficacy as the DPK, but was only $1 \mathrm{~min}$ in duration. 
The ChloraPrep ${ }^{\circledR}$ disinfection method (CareFusion Ltd, Reigate, UK), consisting of a 30-second application of $70 \%$ isopropyl alcohol and $2 \%$ chlorhexidine gluconate with a 30 -second drying time was shown to give equivalent disinfection efficiency as the DPK [13]. In 2006, ChloraPrep was implemented throughout NHSBT for both routine and apheresis donations.

\section{Diversion}

A $47 \%$ reduction in bacterially contaminated blood donations was observed in our study on the effectiveness of diversion [15]. On the basis of this study, diversion was implemented nationally in 2002. Monitoring data derived from testing outdated platelet concentrates showed a $66 \%$ reduction in contamination [16]. Prior to the implementation of diversion in the 3-year period 1999 to 2001, there were 11 clinically apparent cases from NHSBT-produced pooled platelet concentrates $(n=9)$ and red cell units $(n=2)$. After the implementation of diversion in the 3-year period 2003 to 2005 , there were only 2 reports of clinically apparent transmission of bacteria by transfusion, a reduction of $82 \%$ [17].

The NHSBT diversion study also indicated that diversion, together with improved donor arm disinfection, would reduce bacterial contamination by approximately $77 \%$ [15].

\section{Discussion}

Donor arm disinfection is the first physical intervention applied to prevent microbial contamination of a blood donation. Many blood services have now validated and implemented best-practice procedures $[18,19]$. In Canada the DPK system was shown to be a best-practice procedure, a finding confirmed by our studies [20]. Studies in the USA and Canada with the ChloraPrep disinfection device have confirmed the findings of NHSBT [21, 22]. This device has been adopted for use in these countries. Since the work of NHSBT, the evidence-based practice in Infection Control Guidelines Version 2 (epic 2) for National Health Service hospitals in England recommend 'a single patient use application of alcoholic chlorhexidine gluconate solution, preferably $2 \%$ chlorhexi- dine in $70 \%$ isopropyl alcohol' for central venous access device decontamination [23].

The NHSBT diversion study indicated that a $47 \%$ reduction in bacterial contamination would be obtained, although a greater reduction of $66 \%$ was observed in the outdated platelet study, and clinically apparent transmissions were reduced by as much as $82 \%$. Studies in the Netherlands by de Korte et al. [24] and by Olthius et al. [14] showed a $40 \%$ and $82 \%$ reduction respectively. Bruneau et al. [25] in France reported a $72 \%$ and Benjamin et al. in the USA a $54 \%$ reduction in bacterial contamination [26]. Diversion has now been widely adopted by blood services.

Improved donor arm disinfection and diversion have been shown to be highly effective, relatively low-cost interventions for reducing the transmission of bacteria by transfusion. An NHSBT study indicated that improved donor arm disinfection in conjunction with diversion would reduce bacterial contamination by approximately $77 \%$ [27]. Residual contamination levels of blood units after the introduction of diversion may be in the order of $30-40 \%$ [24, 27].

Since 2006, improved donor arm disinfection and diversion have been used for all NHSBT donations. In the period of SHOT haemovigilance 2006-2009, bacterial transmission was reported from 10 NHSBT donations which resulted in 4 deaths [28]. In November 2005 in the UK, it became mandatory to report adverse transfusion reactions, which resulted in an increase in bacterial investigations, revealing more cases of transmission. In 2011, in view of this data, NHSBT implemented bacterial screening of platelet concentrates to further increase the safety of the blood supply.

\section{Acknowledgements}

The author would like to thank Tracy Ward, Siobhan Ancliff, and Professor Barbara for assistance in preparation of this manuscript.

\section{Disclosure Statement}

The author declared no conflicts of interest.

\section{References}

1 Soldan K, Davison K, Dow B: Estimates of the frequency of HBV, HCV, and HIV infectious donations entering the blood supply in the United Kingdom, 1996 to 2003. Euro Surveill 2005;10:17-19.

2 Novak M: Preservation of stored blood with sulfanilamide. JAMA 1939;113:2227-2229.

3 Strumia MM, McGraw JJ: Frozen and dried plasma for civil and military use. JAMA 1941:116:23782382
4 Asher D, Atterbury C L J, Chapman C, Cohen H, Jones H, Love E M, Norfolk D R, Revill J, Soldan K, Todd A, Williamson LM; on behalf of the Serious Hazards of Transfusion (SHOT) Steering Group: The 2000/2001 Annual SHOT Report. www shotuk org/wp-content/uploads/2010/03/SHOTReport-00-01 pdf.

5 Debeir J, Noel L, Allen J-P, Frette C, Sari F, Mai M, Cosson A: The French haemovigilance system. Vox Sang 1999;77:77-81.
6 Morel PC: The French Experience in the Prevention of Transfusion Incidents due to Bacterial Contamination. Bacterial Contamination fo Platelets Workshop, Washington DC, FDA, 1999.

7 Morel P: Bacterial Contamination of Platelets Workshop, Bethseda. www.fda.gov/cber/minutes/ bact092499.pdf.

8 Center for Biologics Evaluation and Research: Workshop on Bacterial Contamination of Platelets, Bethesda. 1999. www.fda.gov/cber/minutes/ workshop-min.htm. 
9 Goldman M, Webert KE, Arnold DM: Proceedings of a consensus conference: towards an understanding of TRALI. Transfus Med Rev 2005;19:2-31.

10 McDonald CP, Roy A, Lowe P, Robbins S, Hartley S, Barbara JA: Evaluation of the BacT/Alert automated blood culture system for detecting bacteria and measuring their growth kinetics in leucodepleted and non-leucodepleted platelet concentrates. Vox Sang 2001;81:154-160.

11 McDonald CP, Rogers A, Cox M, Smith R, Roy A, Robbins S, Hartley S, Barbara JA, Rothenberg S, Stutzman L, Widders G: Evaluation of the 3D BacT/ALERT automated culture system for the detection of microbial contamination of platelet concentrates. Transfus Med 2002;12:303-309.

12 McDonald CP, Lowe P, Roy A, Robbins S, Hartley S, Harrison JF, Slopecki A, Verlander N, Barbara JA: Evaluation of donor arm disinfection techniques. Vox Sang 2001;80:135-141.

13 McDonald C, McGuane S, Thomas J, Hartley S, Robbins S, Roy A, Verlander N, Barbara J: a novel rapid and effective donor arm disinfection method. Transfusion 2010;50:53-58.

14 Olthuis H, Puylaert C, Verhagen C, Valk L: Method for removal of contamination bacteria during venepuncture. Presented at the 5th International Society of Blood Transfusion Regional Congress, Venice, Italy July 2-5, 1995 ..

15 McDonald CP, Roy A, Mahajan P, Smith R, Charlett A, Barbara JA: Relative values of the interventions of diversion and improved donor-arm disinfection to reduce the bacterial risk from blood transfusion. Vox Sang 2004:86:178-182.
16 McDonald C, Colvin J, Biggs C, Goodhand K, Harden G, McGuane S: Do diversion and improved donor arm disinfection reduce bacterial contamination in platelet concentrates. Transfusion 2005;45:56A (Abstract)

17 Stainsby D, Jones H, Cohen H, Asher A, Atterbury C, Boncinelli A, Brant L, Chapman CE, Knowles S, Milkins C, Norfolk DR; on behalf of the Serious Hazards of Transfusion (SHOT) Steering Group: The 2005 Annual SHOT Report . www shotuk org/ wp-content/uploads/2010/03/SHOT-report-2005 $p d f$

18 Wong PY, Colville VL, White V, Walker HM, Morris RA: Validation and assessment of a blooddonor arm disinfectant containing chlorhexidine and alcohol. Transfusion 2004;44:1238-1242.

19 Lee CK, Ho PL, Chan NK, Mak A, Hong J, Lin CK: Impact of donor arm skin disinfection on the bacterial contamination rate of platelet concentrates. Vox Sang 2002;83:204-208.

20 Goldman M, Roy G, Frechette N, Decary F, Massicotte L, Delage G: Evaluation of donor skin disinfection methods. Transfusion 1997;37:309-312.

21 Ramirez-Arcos S, Goldman M: Skin disinfection methods: prospective evaluation and postimplementation results. Transfusion 2010;50:59-64.

22 Benjamin RJ, Dy B, Warren R, Lischka M, Eder AF: Skin disinfection with a single-step $2 \%$ chlorhexidine swab is more effective than a two-step povidone-iodine method in preventing bacterial contamination of apheresis platelets. Transfusion 2011;51:531-538.
3 Pratt RJ, Pellowe CM, Wilson JA, Loveday HP, Harper PJ, Jones SR, McDougall C, Wilcox MH: epic2: National evidence-based guidelines for preventing healthcare-associated infections in NHS hospitals in England. J Hosp Infect 2007; 65(suppl 1):S1-64.

24 de Korte D, Marcelis JH, Verhoeven AJ, Soeterboek AM: Diversion of first blood volume results in a reduction of bacterial contamination for whole-blood collections. Vox Sang 2002;83:13-16.

25 Bruneau C, Perez P, Chassaigne M, Allouch P, Audurier A, Gulian C, Janus G, Boulard G, De Micco P, Salmi LR, Noel L: Efficacy of a new collection procedure for preventing bacterial contamination of whole-blood donations. Transfusion 2001;41:74 81.26 Benjamin RJ, Kline L, Dy BA, Kennedy J, Pisciotto P, Sapatnekar S, Mercado R, Eder AF Bacterial contamination of whole-blood-derived platelets: the introduction of sample diversion and prestorage pooling with culture testing in the American Red Cross. Transfusion 2008;48:23482355.

27 McDonald CP, Roy A, Mahajan P, Smith R, Charlett A, Barbara JA: Relative values of the interventions of diversion and improved donor-arm disinfection to reduce the bacterial risk from blood transfusion. Vox Sang 2004;86:178-182.

28 Taylor C (ed), Cohen H, Mold D, Jones H, Davies T, Mistry H, Ball J, Asher D, Cawley C, Chaffe B, Chapman C, Gray A; on behalf of the Serious Hazards of Transfusion (SHOT) Steering Group: The 2009 Annual SHOT report. $w w w$ shotuk org/wp-content/uploads/2010/07/SHOT2009 pdf. 